\title{
Calcium Salts Enhance Activity and Azo Dye Decolourisation Capacity of Crude Peroxidase from Armoracia rusticana
}

\author{
Mugdha Ambatkar, Usha Mukundan
}

Plant Biotechnology Laboratory, Ramniranjan Jhunjhunwala College, Mumbai, India.

Email: umukundan@hotmail.com

Received October $4^{\text {th }}, 2013$; revised November $18^{\text {th }}, 2013$; accepted December $1^{\text {st }}, 2013$

Copyright (C) 2014 Mugdha Ambatkar, Usha Mukundan. This is an open access article distributed under the Creative Commons Attribution License, which permits unrestricted use, distribution, and reproduction in any medium, provided the original work is properly cited. In accordance of the Creative Commons Attribution License all Copyrights (C) 2014 are reserved for SCIRP and the owner of the intellectual property Mugdha Ambatkar, Usha Mukundan. All Copyright @ 2014 are guarded by law and by SCIRP as a guardian.

\begin{abstract}
Armoracia rusticana is the commercial source of the enzyme Horseradish Peroxidase (HRP). Calcium ions play an important role in the functional conformation of HRP. The present study assesses the effect of three calcium salts viz., calcium chloride $\left(\mathrm{CaCl}_{2}\right)$, calcium nitrate $\left[\mathrm{Ca}\left(\mathrm{NO}_{3}\right)_{2}\right]$ and calcium sulphate $\left(\mathrm{CaSO}_{4}\right)$ on the guaiacol activity of crude peroxidase extracted from the shoots and roots of in vitro grown plantlets of $A$. rusticana and their growth medium. The highest activity was observed in the shoot extracts of $25 \mathrm{mM} \mathrm{CaCl}_{2}$ treated plantlets $(1.92 \mathrm{U} / \mathrm{mL})$ and the root extracts of $25 \mathrm{mM} \mathrm{Ca}\left(\mathrm{NO}_{3}\right)_{2}$ supplemented plantlets $(2.84 \mathrm{U} / \mathrm{mL})$. The crude peroxidase activity of the medium containing $25 \mathrm{mM} \mathrm{CaCl}_{2}$ supplement was highest $(0.13 \mathrm{U} / \mathrm{mL})$. The capacity of the shoot and root extracts to decolourise a $10 \mathrm{ppm}$ solution of methyl orange over 48 hours, was also tested. The decolourisation capacity was highest in the shoot extracts from $\mathrm{CaCl}_{2}$ treated plantlets $(49.32 \%)$ and root extracts from $\mathrm{Ca}\left(\mathrm{NO}_{3}\right)_{2}$ treated plantlets $(29.72 \%)$ respectively. Hence, the addition of calcium salts to growth medium enhances both peroxidase activity and decolourisation capacity of crude extracts of $A$. rusticana plantlets. These findings are of significance in enzymatic treatment for decolourisation of effluents containing dyestuffs.
\end{abstract}

\section{KEYWORDS}

Peroxidase; Armoracia Rusticana; Calcium; Decolourisation; Azo Dye

\section{Introduction}

The herb Armoracia rusticana P. Gaertn, B. Mey. \& Scherb. is the commercial source of the enzyme peroxidase, i.e. Horseradish peroxidase (HRP) which has several diagnostic uses [1]. Some of the uses of HRP in clinical diagnosis include the determination of hydrogen peroxide $\left(\mathrm{H}_{2} \mathrm{O}_{2}\right)$ in biological systems and the labeling of antibodies. In recent times, the use of HRP has become common in diverse fields including enzymatic waste water treatment.

Peroxidases are cell-wall associated enzymes [2]. The enzyme HRP is a ferric ion containing heme enzyme. Calcium acts to maintain the functional conformation of some proteins like Horseradish Peroxidase [1]. Studies with lignin peroxidase have shown that calcium ions are important for the heme environment of the enzyme and thereby affect its activity $[3,4]$. The role of calcium in the growth of plants and in the maintenance of their health has been studied extensively. Calcium ions $\left(\mathrm{Ca}^{2+}\right)$ are an important component of plant cell walls. The $\mathrm{Ca}^{2+}$ that are present in the middle lamella between adjacent cells hold the cell wall components together [5]. Calcium is also known to affect cell wall permeability. Salts like calcium chloride and calcium phosphate are known to increase the permeability of bacterial cell walls and animal cell membranes respectively, making them more competent to take up foreign DNA [6]. Calcium ions have been reported to affect the in vivo activity of peroxidases in plants [7]. Experiments by Stitcher et al. (1981) [8] and Kwak et al. (1996) [9], and our pilot studies (data not shown), have revealed that peroxidase 
activity increases in the presence of $\mathrm{Ca}^{2+}$ in the form of calcium chloride $\left(\mathrm{CaCl}_{2}\right)$.

In the present study, plantlets of A. rusticana were grown in vitro in media supplemented with three different salts of calcium, namely $\mathrm{CaCl}_{2}, \mathrm{Ca}\left(\mathrm{NO}_{3}\right)_{2}$ and $\mathrm{CaSO}_{4}$, to study the effect of the calcium supplements on the activity of crude peroxidase extracted from the shoots and roots of these plantlets. The media in which the plantlets were grown contained peroxidase secreted by them (extracellular peroxidase). The peroxidase activity of each of the media was assayed as well. The capacity of the shoot and root extracts to decolourise an aqueous solution of methyl orange over 48 hours was also assessed.

\section{Materials and Methods}

\subsection{Multiplication of in Vitro Cultures of $A$. rusticana Plantlets}

The in vitro plantlets of Armoracia rusticana were subcultured every 4 - 6 weeks on modified Murashige and Skoog's (MS) medium [10] supplemented with 3\% sucrose and $0.5 \mathrm{mg} \cdot \mathrm{L}^{-1}$ Indole-3-acetic acid (IAA). The explants used included leaf, petiole and node.

\subsection{Preparation of Crude Enzyme Extract}

A known weight (about $0.2 \mathrm{~g}$ ) of each plant tissue was macerated in a pre-chilled mortar and pestle with $2.0 \mathrm{~mL}$ of $0.1 \mathrm{M}$ phosphate buffer ( $\mathrm{pH}$ 5.8). The macerated suspension was cold centrifuged at $5000 \mathrm{rpm}$ for $5 \mathrm{~min}$. The supernatant was collected and used as the source of enzyme. The protein content of crude enzyme extract was determined using the method of Lowry et al. (1951) [11]. The crude extracts prepared from shoot tissues contained chlorophylls. The absorbance due to chlorophylls was compensated using appropriate corrections.

\subsection{Determination of Activity of Crude Enzyme Extracts}

The activity of peroxidase was estimated spectrophotometrically using a JASCO V-530 spectrophotometer based on the method described by Kim and Yoo (1996) [12]. In this assay, the colored product, i.e. tetraguaiacol $\left(\varepsilon=26600 \mathrm{~L} \cdot \mathrm{mol}^{-1} \cdot \mathrm{cm}^{-1}\right)$, is estimated at $470 \mathrm{~nm}$. The reaction mixture $(3.0 \mathrm{~mL})$ contained $0.9 \mathrm{~mL}$ of $0.1 \mathrm{M}$ phosphate buffer (pH 6.0), $1.0 \mathrm{~mL}$ of $15 \mathrm{mM}$ guaiacol i.e. 2-methoxy phenol (substrate), $0.1 \mathrm{~mL}$ of crude enzyme extract and $1.0 \mathrm{~mL}$ of $3 \mathrm{mM}$ hydrogen peroxide.

The activity of an enzyme is expressed as units per $\mathrm{mL}$ $(\mathrm{U} / \mathrm{mL})$. One unit $(\mathrm{U})$ is defined as the amount of enzyme that can convert $1 \mu$ mole of substrate into product in 1 minute. Throughout the study, the activity of peroxidase in the crude extracts has been calculated using the following formula shown in Equation (1) (using guaiacol as substrate):

$$
\mathrm{U} / \mathrm{ml}=\frac{\Delta \mathrm{OD} / \mathrm{min} \times \mathrm{RmV} \times \mathrm{df}}{\varepsilon_{470} \times \mathrm{EV}}
$$

where,

$\Delta \mathrm{OD} / \mathrm{min}=$ change in absorbance per minute

$\mathrm{RmV}=$ reaction mixture volume $(\mathrm{mL})$

$\mathrm{df}=$ dilution factor

$\varepsilon_{470}=$ molar absorptivity of tetraguaiacol at $470 \mathrm{~nm}$

$\left(\mathrm{mL} \cdot \mu \mathrm{mol}^{-1} \cdot \mathrm{cm}^{-1}\right)$

$\mathrm{EV}=$ enzyme extract volume $(\mathrm{mL})$

\subsection{Comparison of Peroxidase Activity in Terms of Equivalence to Standard HRP}

The activity of the crude extracts has been compared to that of standard Horseradish Peroxidase (HRP). The standard used had an activity of $250 \mathrm{U} / \mathrm{mg}$ (HiMedia India Ltd.). The number of equivalents of the standard $\mathrm{HRP} / \mathrm{mL}$ present in the crude extracts was calculated. The calculation was based on the rate of reaction vs. concentration of standard enzyme (graph not shown) under reaction conditions identical to the ones used for the assay of the crude extracts.

\subsection{Determination of Optimum Concentration of Calcium Chloride}

In these experiments, in vitro plantlets of A. rusticana were grown in modified (MS) liquid media supplemented with $0,5,10,25,50$ and $100 \mathrm{mM} \mathrm{CaCl}_{2}$ for a period of 21 days in culture bottles. The temperature was maintained at $25^{\circ} \mathrm{C} \pm 2^{\circ} \mathrm{C}$ with 16 hours light and 8 hours dark photoperiod. The shaker speed was adjusted to $80 \mathrm{rpm}$. The guaiacol activity of shoot and root extracts and that of the medium was assayed at the end of the growth period.

\subsection{Selection of Calcium Salts as Supplements}

The two salts of calcium other than $\mathrm{CaCl}_{2}$ that were selectedas supplements included calcium nitrate $\left[\mathrm{Ca}\left(\mathrm{NO}_{3}\right)_{2}\right]$ and calcium sulphate $\left(\mathrm{CaSO}_{4}\right)$. These two salts are used as liquid fertilizer and as a soil amendment respectively. All the three salts used viz., $\mathrm{CaCl}_{2} \cdot 2 \mathrm{H}_{2} \mathrm{O}, \mathrm{Ca}\left(\mathrm{NO}_{3}\right)_{2} \cdot 4 \mathrm{H}_{2} \mathrm{O}$ and $\mathrm{CaSO}_{4} \cdot 2 \mathrm{H}_{2} \mathrm{O}$ were purchased from Loba Chemie (Mumbai).

\subsection{Inoculation of Plantlets on Media Supplemented with Different Calcium Salts}

In the studies with different concentrations of $\mathrm{CaCl}_{2}$, media supplemented with $25 \mathrm{mM} \mathrm{CaCl} 2$ showed higher peroxidase activity than the MS (P) i.e. control and with greater consistency (shoot, root and media) than the other 
concentrations. Hence, in the studies with different calcium salts, the final concentration of each calcium supplement was maintained at $25 \mathrm{mM}$. Accordingly, single rooted plantlets, weighing about $0.1 \mathrm{~g}$ each, were inoculated in culture bottles containing $30 \mathrm{~mL}$ of liquid medium. The media used were as given in Table 1 .

\subsection{Decolourisation of Methyl Orange by Shoot and Root Extracts}

The shoot and root extracts of the A. rusticana plantlets grown in media supplemented with different calcium salts were also tested for their ability to decolourise methyl orange, a monoazo dye, at a final concentration of 10 ppm over 48 hours. This experiment would help to assess the potential of growth medium supplements to enhance the performance of peroxidases from A. rusticana in enzymatic treatment of wastewater. The activity of the media was very low and hence they were not used in the decolourisation studies. The compositions of the reaction mixtures are as shown in Table 2.

The absorbance was recorded at the start of the reaction and after 48 hours. Controls devoid of enzyme extract were maintained to account for decolourisation due to the bleaching action of hydrogen peroxide. Hydrogen peroxide is a widely used commercial bleaching agent. Also, a set of reaction mixtures containing $10 \mathrm{ppm}$ methyl orange and the Fenton reagent [13] was maintained as positive control for decolourisation. Decrease in the absorbance was measured and the percentage decolourisation was calculated using the following formula shown in Equation (2):

Table 1. Growth media composition.

\begin{tabular}{cc}
\hline Sr. No. & Medium and supplement \\
\hline 1 & Modified MS medium \\
2 & Modified MS medium $+25 \mathrm{mM} \mathrm{CaCl}_{2}$ \\
3 & Modified MS medium $+25{\mathrm{mM} \mathrm{Ca}\left(\mathrm{NO}_{3}\right)_{2}}_{4}$ \\
\hline
\end{tabular}

Table 2. Components of reaction mixture for methyl orange decolourisation study.

\begin{tabular}{ccc}
\hline Reaction mixture components & Shoot & Root \\
\hline $0.1 \mathrm{mg} \cdot \mathrm{L}^{-1}$ phosphate buffer $(\mathrm{pH} 6.0)$ & $1.46 \mathrm{~mL}$ & $1.76 \mathrm{~mL}$ \\
Crude enzyme extract & $0.5 \mathrm{~mL}$ & $0.2 \mathrm{~mL}$ \\
Dilution factor & 1 & 1 \\
$30 \mathrm{mg} \cdot \mathrm{L}^{-1}$ methyl orange & $1.0 \mathrm{~mL}$ & $1.0 \mathrm{~mL}$ \\
$300 \mathrm{mmol} \cdot \mathrm{L}^{-1}$ hydrogen peroxide & $0.04 \mathrm{~mL}$ & $0.04 \mathrm{~mL}$ \\
Total volume of reaction mixture & $\mathbf{3 . 0 ~} \mathbf{~ L L}$ & $\mathbf{3 . 0 ~} \mathbf{~ m L}$ \\
\hline
\end{tabular}

$$
\text { Decolourisation } \%=\frac{A_{i}-A_{f}}{A_{i}} \times 100
$$

where,

$$
\begin{aligned}
& A_{i}=\text { initial absorbance } \\
& A_{f}=\text { final absorbance }
\end{aligned}
$$

\subsection{Statistical Analysis of Data}

The reported values are mean \pm SD $(n=3)$. All the statistical analysis of the data obtained from the studies described above, were performed using SPSS version 19. The results of the analysis were obtained for $p<0.05$. In cases where ANOVA has been performed, multiple comparisons were made using Duncan's Multiple Range Test (DMRT). The "shoot" series has been assigned groups represented by the lower case letters a, b and c (where, a > b > c). The "root" series has been assigned groups represented by the upper case letters $\mathrm{A}, \mathrm{B}$ and $\mathrm{C}$ (where, A > B > C). The "media" series has been assigned groups represented by upper case letters $\mathrm{X}, \mathrm{Y}$ and $\mathrm{Z}$ (where, $\mathrm{X}>\mathrm{Y}>\mathrm{Z}$ ).

The means (within a single series, i.e. shoot, root or media) that have been assigned the same letter(s) are not significantly different from each other at $p<0.05$.

\section{Results}

\subsection{Determination of Optimum Concentration of Calcium Chloride}

As seen in Figure 1, among the treatments, the highest activity of shoot peroxidase is seen at $25 \mathrm{mM} \mathrm{CaCl}_{2}$ $(1.76 \mathrm{U} / \mathrm{mL})$ and $25 \mathrm{mM}(1.87 \mathrm{U} / \mathrm{mL}) \mathrm{CaCl}_{2}$. The activity at $10,25,50$ and $100 \mathrm{mM} \mathrm{CaCl}{ }_{2}$ is significantly higher than in the control set $0 \mathrm{mM}$ i.e. MS (P). Among the treated samples the maximum activity of the medium was seen at $25 \mathrm{mM} \mathrm{CaCl} 2(0.43 \mathrm{U} / \mathrm{mL})$ followed by 10 $\mathrm{mM}(0.41 \mathrm{U} / \mathrm{mL})$ and $50 \mathrm{mM}(0.39 \mathrm{U} / \mathrm{mL})$. The activity

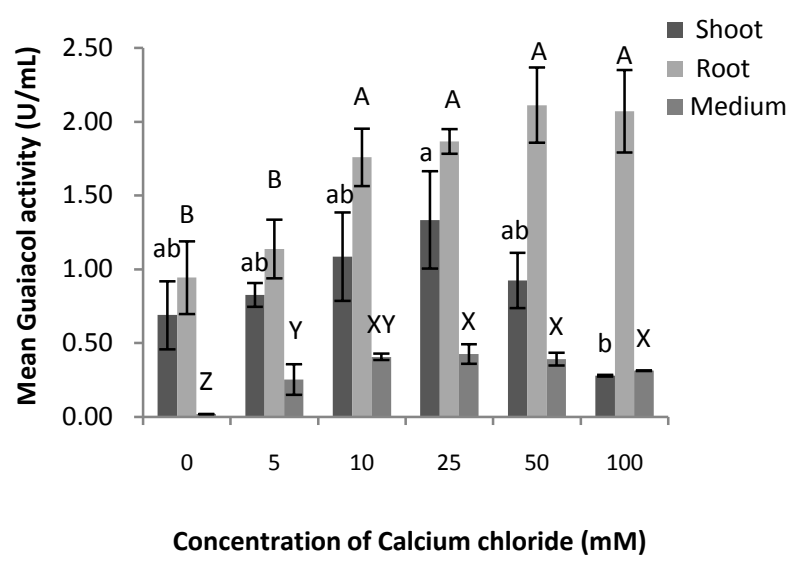

Figure 1. Comparison of activity of crude peroxidase from shoot, root extracts and medium at different concentrations of calcium chloride. 
at 10,25 and $50 \mathrm{mM}$ is significantly higher than that of the MS (P) control.

The $25 \mathrm{mM} \mathrm{CaCl}_{2}$ treatment shows consistently higher peroxidase activity across shoots, roots and media than other concentrations. Hence, $25 \mathrm{mM}$ was selected as the concentration to work with other calcium salts as well.

\subsection{Effect of Calcium Salt Supplement on Crude Peroxidase Activity}

The activity of crude peroxidase from the shoots, roots and media of plantlets grown with different calcium salts is shown in Figure 2. Among the shoot extracts, the highest activity is found in the shoots that received 25 $\mathrm{mM} \mathrm{CaCl}{ }_{2}$ treatment $(1.92 \mathrm{U} / \mathrm{mL})$ which is significantly higher than the control and other treatments. The activity of crude peroxidase from the roots of plantlets grown in presence of $25 \mathrm{mM} \mathrm{Ca}\left(\mathrm{NO}_{3}\right)_{2}$ is significantly higher $(2.84 \mathrm{U} / \mathrm{mL})$ than the control set as well as that of roots from other treatments. The activity of medium supplemented with $25 \mathrm{mM} \mathrm{CaCl}{ }_{2}$ is significantly higher $(0.13$ $\mathrm{U} / \mathrm{mL}$ ) than the activity of the control set media and that of the media from other treatments. However, the activity of the media was generally low and hence the media were not used for subsequent decolourisation studies.

As seen in Figure 3 the extracts made from of shoots of A. rusticana plantlets grown with $25 \mathrm{mM} \mathrm{CaCl}_{2}$ have the highest number of standard HRP equivalent units (0.82) per milliliter. This is significantly higher than the number of equivalents in the extracts made from the shoots of control plantlets or those of the other treatments. The extracts made from the roots of $A$. rusticanaplantlets grown in medium supplemented with $25 \mathrm{mM} \mathrm{Ca}\left(\mathrm{NO}_{3}\right)_{2}$ showed significantly higher number of standard HRP equivalent units (1.22) per milliliter, than the control roots or the roots that were given other calcium supplements. The medium of A. rusticana plantlets with $25 \mathrm{mM} \mathrm{CaCl}_{2}$

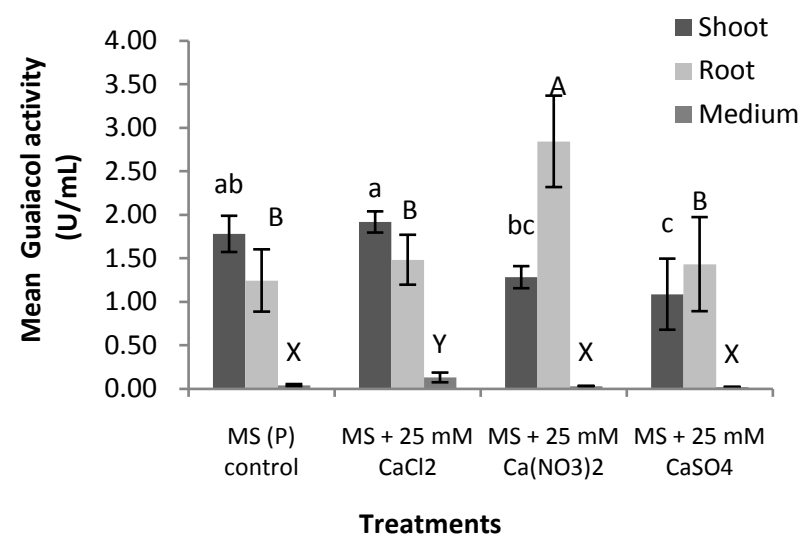

Figure 2. Comparison of peroxidase activity of crude extracts from shoots, root and medium of $A$. rusticana plantlets grown in media supplemented with different calcium salts.

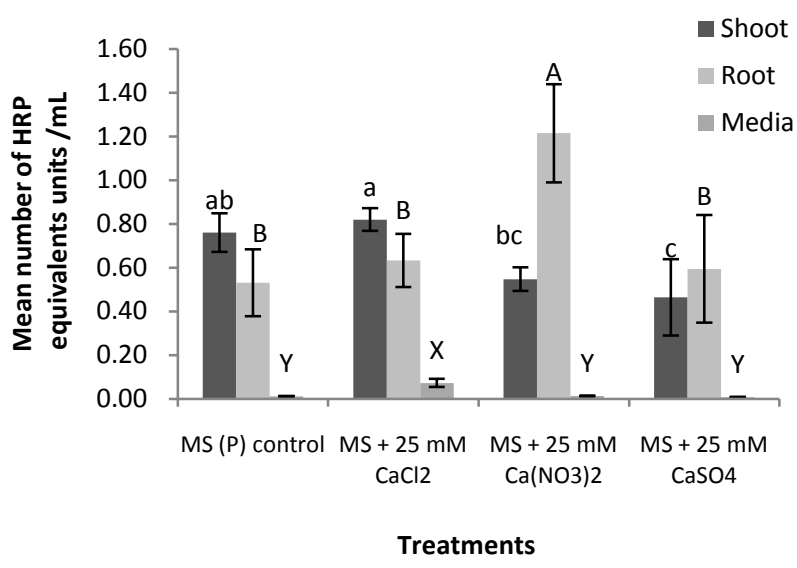

Figure 3. Comparison of number of equivalent units of standard HRP in shoot and root extracts and medium of $A$. rusticana plantlets grown in medium supplemented with different salts of calcium.

supplement shows significantly higher number of standard HRP equivalent units (0.07) per milliliter than the control or other treatments.

\subsection{Effect of Presence of Calcium Salt Supplement in Plant Growth Medium on Decolourising Capacity of Extracts}

As seen from Figure 4, the shoot extracts from plantlets grown in medium supplemented with $25 \mathrm{mM} \mathrm{CaCl}_{2}$ show the highest capacity for decolourisation (49.32\%) of $10 \mathrm{ppm}$ methyl orange over 48 hours. The crude peroxidase from the roots of plantlets grown in medium supplemented with $\mathrm{Ca}\left(\mathrm{NO}_{3}\right)_{2}$ show the highest decolourisation (29.72\%) over 48 hours which is significantly higher than decolourisation capacities of extracts from roots grown with other supplements or MS control. An enzyme control that was devoid of any enzyme extract was also maintained in order to account for the decolourisation that may occur due to the bleaching action of hydrogen peroxide. The bleaching effect however was very small as compared to the decolourisation obtained in the enzyme treated sets. The positive control treated with the Fenton process showed $96.51 \%$ decolourisation over 48 hours.

\section{Discussion}

A pilot study (data not shown) was conducted to test the effect of various growth media supplements on the peroxidase activity from plantlets of $A$. rusticana (intracellular peroxidase) and that of the medium (extracellular peroxidase). The plantlets treated with calcium chloride $\left(\mathrm{CaCl}_{2}\right)$ and their growth medium showed significantly higher peroxidase activity as compared to untreated plantlets. This led to questions regarding the concentration of $\mathrm{CaCl}_{2}$ at which the enhancement of peroxidase activity 


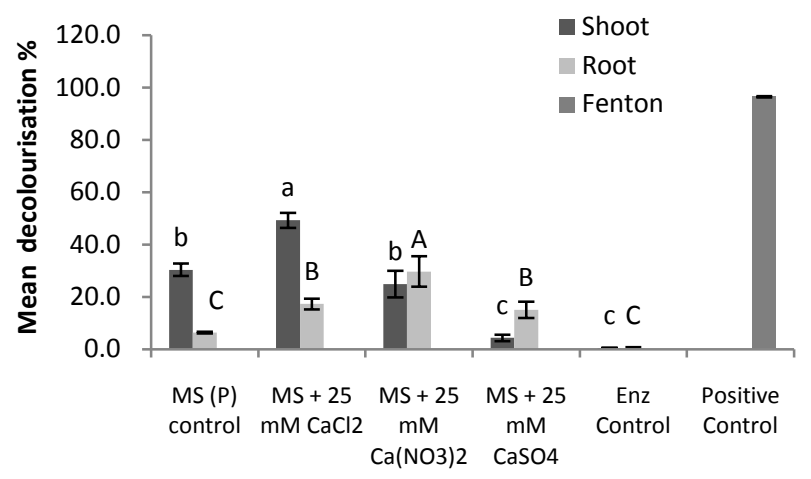

Treatments

Figure 4. Comparison of decolourisation of $10 \mathrm{ppm}$ methyl orange over 48 hours using crude peroxidase extracts from shoots and roots of $A$. rusticana plantlets grown with different calcium salts.

was consistently observed and whether or not other salts of calcium could produce a similar effect.

It is known that $\mathrm{CaCl}_{2}$ increases permeability of bacterial cell walls [6]. In plants too, calcium ions $\left(\mathrm{Ca}^{2+}\right)$ play a role in modifying the permeability of cell wall. Studies have shown that lower concentrations of $\mathrm{Ca}^{2+}$ can increase the permeability of cell walls while higher concentrations can make the cell walls rigid and less plastic [14]. This effect is indicated in Figure 1 which shows the peroxidase activity of medium (which contains extracellular or secreted peroxidase) at different concentrations of $\mathrm{CaCl}_{2}$. It appears that the secretion of peroxidase into medium increases up to and is highest at $25 \mathrm{mM} \mathrm{CaCl}_{2}$. Above this concentration, the activity is lower (though not significantly), presumably due to reduction in permeability resulting in decreased secretion of peroxidase. The enhanced release of peroxidase by cell cultures of spinach in the presence of $1 \mathrm{mM} \mathrm{CaCl}_{2}$ has been reported earlier [8]. Since consistently high peroxidase activity was seen with calcium chloride at 25 $\mathrm{mM}$, this concentration was selected for further experiments involving two more salts of calcium (as supplements); viz., calcium nitrate $\left[\mathrm{Ca}\left(\mathrm{NO}_{3}\right)_{2}\right]$ and calcium sulphate $\left[\mathrm{CaSO}_{4}\right]$.

Shoots of plantlets supplemented with $25 \mathrm{mM} \mathrm{CaCl}_{2}$ showed significantly higher peroxidase activity than the shoots of control and those grown with other calcium supplements. An earlier report in sweet potato [9] has also shown an increase in intracellularperoxidase on treatment with $\mathrm{CaCl}_{2}$. The extracts from shoots of $\mathrm{CaCl}_{2}$ treated plantlets showed significantly higher number of equivalents of standard Horseradish Peroxidase (HRP) units per milliliter than the shoots of control and those grown with other calcium supplements.

The roots of all calcium treated plantlets showed higher peroxidase activity than the control, indicating some enhancement by the addition of calcium. However, the roots of plantlets supplemented with $25 \mathrm{mM}$ $\mathrm{Ca}\left(\mathrm{NO}_{3}\right)_{2}$ showed significantly higher peroxidase activity than the roots of control plantlets and plantlets treated with $\mathrm{CaCl}_{2}$ or $\mathrm{CaSO}_{4}$. This suggests that the higher concentration of nitrate ions $\left(\mathrm{NO}_{3}^{-}\right)$in the $\mathrm{Ca}\left(\mathrm{NO}_{3}\right)_{2}$ treated set may have contributed to an additional increase in peroxidase activity in these roots. The peroxidase activity in roots of tomato plants treated with $\mathrm{Ca}\left(\mathrm{NO}_{3}\right)_{2}$ has been reported to be significantly higher than in roots of untreated plants [15]. Similarly, the peroxidase activity in the roots of transgenic tobacco plants was found to increase with an increasing concentration of $\mathrm{NO}_{3}^{-}$in the growth medium [16]. The root extracts of $A$. rusticanaplantlets treated with $\mathrm{Ca}\left(\mathrm{NO}_{3}\right)_{2}$, in the present study showed the highest number of equivalents of standard Horseradish Peroxidase (HRP) units per milliliter. It is likely that the presence of many isoenzymes of peroxidase in the plant parts of A. rusticana [1] justifies the observation that different plant parts showed enhanced peroxidase activity in the presence of different calcium salts.

The media of plantlets treated with $25 \mathrm{mM} \mathrm{CaCl}_{2}$ showed significantly higher peroxidase activity compared to the control and other treatments. This is probably due to the cell wall permeability enhancing property of $\mathrm{CaCl}_{2}$. The media of $\mathrm{CaCl}_{2}$ treated plantlets showed significantly higher number of equivalents of standard Horseradish Peroxidase (HRP) units per milliliter than the plantlets given another or no calcium supplement.

Based on the observation that the activity of peroxidase from $A$. rusticanashoot and root increased on addition of $\mathrm{CaCl}_{2}$ and $\mathrm{Ca}\left(\mathrm{NO}_{3}\right)_{2}$ in the growth media respectively, the effect of these calcium salts on the dye decolourisation capacity of peroxidase was studied. Studies were conducted using $10 \mathrm{ppm}$ of the mono-azo dye methyl orange over a period of 48 hours. Pilot studies have shown that the root and shoot extracts of $A$. rusticana plantlets could bring about appreciable decolourisation of methyl orange in 48 hours (data not shown). This observation could have important application in enzymatic treatment of wastewater containing dyestuff. The bleaching of the dye due to hydrogen peroxide has been accounted for in the studies by using suitable control sets. The positive control for decolourisation was the treatment of $10 \mathrm{ppm}$ methyl orange using the Fenton reagent. The Fenton process is a widely used advanced oxidation process for the mineralization of azo dyes [17]. The drawbacks of this method however, are the requirement of highly acidic conditions, the introduction of soluble ions and the need to regenerate $\mathrm{Fe}^{2+} / \mathrm{Fe}^{3+}$ at the end of each cycle [18]. Azo dyes are widely used in the textile and leather industry due to their high tinctorial strength. However, their stability hinders 
their degradation and has led to their classification as recalcitrant pollutants [19]. Enzymatic treatment of industrial effluents is steadily gaining importance due to its efficiency and environment-friendliness [19].

When the shoot and root extracts of A. rusticana plantlets treated with calcium salts were used for decolourisation of methyl orange, higher decolourisation was expected due to higher peroxidase activity. Shoot extracts of A. rusticana plantlets treated with $25 \mathrm{mM} \mathrm{CaCl}_{2}$ showed significantly higher decolourisation than control or other treatments. The root extracts of the plantlets treated with $25 \mathrm{mM} \mathrm{Ca}\left(\mathrm{NO}_{3}\right)_{2}$ showed significantly higher decolourisation than the control or other treatments. The root extracts of plantlets treated with $\mathrm{CaCl}_{2}$ and $\mathrm{CaSO}_{4}$ also showed significantly higher decolourisation than the control. This observation suggests that incorporating a calcium supplement in the growth medium improves the dye decolourisation capacity of crude root peroxidases from $A$. rusticana. This effect may be due to the role of calcium in maintaining the functional conformation and regulating the catalytic properties of peroxidases [20]. The decolourisation experiments with the medium were inconclusive since the medium showed low activity and supported bacterial growth. Hence, the potential of extracellular peroxidase from the untreated and calcium treated plantlets could not be assessed for the decolourisation of methyl orange.

The addition of calcium to the growth medium of in vitro cultures of Armoracia rusticana enhanced the activity of peroxidase. Quantitative and qualitative variations in peroxidases are observed in response to stress conditions. Peroxidase activity is also known to depend on calcium. Calcium ions act as secondary messengers within cells. The concentration of intracellular calcium also changes in response to various stimuli [21]. Changes in the concentration and/or availability of $\mathrm{Ca}^{2+}$ could therefore lead to changes in the activity of peroxidases. The activation and inactivation of peroxidases in the presence and absence of calcium (as $5 \mathrm{mM} \mathrm{CaCl}_{2}$ ) respectively, have been reported in Raphinus sativus [22].

Structural studies on the enzyme horseradish peroxidase C (HRP C) have shown that it contains two types of metal centers, the heme group and two atoms of calcium. Both these metal centers are necessary for the structural and functional integrity of the enzyme. The calcium atoms are positioned proximally and distally in relation to the heme group and are connected to the heme-binding region by hydrogen bonds. The removal of calcium adversely affects the activity and the thermal stability of the enzyme, and modifies the heme environment [1]. It has been demonstrated that in the presence of calcium, the free-energy during unfolding of native HRP C is much greater than in the absence of calcium. This shows that calcium enhances the stability of the enzyme [23]. The presence of calcium is also essential for the proper folding of HRP C [24].

The addition of calcium salts to the growth medium of A. rusticana plantlets may work in two separate ways to enhance the activity of intra and extracellular peroxidases. The uptake of $\mathrm{Ca}^{2+}$ by plant tissues may enhance the activity of intracellular peroxidase by activation of peroxidases by $\mathrm{Ca}^{2+}$. This effect is often observed on only some isoforms of peroxidase present in a given tissue [18]. A. rusticana plantlets contain several isoenzymes of HRP, fifteen of which have been isolated from the root alone [1]. The presence of many isoenzymes of peroxidase in the plant parts of Armoracia rusticana may justify why different plant parts showed enhanced peroxidase activity in the presence of different calcium salts since different isoforms (isoenzymes) may differ in the concentration of $\mathrm{Ca}^{2+}$ required for their activation. It was found that, calcium chloride provides the highest concentration of $\mathrm{Ca}^{2+}$ in terms of the percentage of the molecular mass that calcium contributes (27.2\%) as compared to calcium nitrate (16.9\%) and calcium sulphate (23.2\%). Also, $\mathrm{CaCl}_{2}$ has a higher solubility in water than $\mathrm{CaSO}_{4}$ and therefore provides more easily available $\mathrm{Ca}^{2+}$ than does $\mathrm{CaSO}_{4}$. It is also likely that the increased peroxidase activity of the shoot extracts and root extracts of calcium treated plantlets resulted from better stability of peroxidase, due to the presence of calcium. It has been suggested that the enhancing effect of calcium on the activity of HRP is due to its influence on the conformation of the heme binding site [25]. The relatively higher concentration of $\mathrm{Ca}^{2+}$ in the tissues of treated plantlets may have been able to maintain the functional conformation of the heme region of the peroxidases present in those tissues, thereby enhancing peroxidase activity. It is possible that different isoenzymes of horseradish peroxidase, present in different tissues require different concentrations of $\mathrm{Ca}^{2+}$ to show such enhancement of activity.

The effect of $\mathrm{Ca}^{2+}$ on the permeability of cell walls is known [5]. In the case of extracellular peroxidase activity, it is likely that the additional calcium in the medium modified the permeability of the cell wall allowing more secretion of peroxidases (associated with cell walls). As expected, this effect was observed in the media of the plantlets treated with $\mathrm{CaCl}_{2}$, which is known to increase cell wall permeability [6].

Since it is also likely that the anions in the calcium salts also influence peroxidase activity, further investigation in that area is needed.

\section{Acknowledgements}

The authors would like to thank UGC (University Grants Commission) for financial assistance for the Major Research Project [F. No. 38-179/2009 (SR) Dated 24 
December 2009] and the fellowship provided to the first author.

\section{REFERENCES}

[1] N. C. Veitch, "Horseradish Peroxidase: A Modern View of a Classical Enzyme,” Phytochemistry, Vol. 65, No. 3, 2004, pp. 249-259. http://dx.doi.org/10.1016/j.phytochem.2003.10.022

[2] A. Vianello, M. Zancani, G. Nagy and F. Macri, "Guaiacol Peroxidase Associated to Soybean Root Plasma Membranes Oxidizes Ascorbate,” Journal of Plant Physiology, Vol. 150, No. 5, 1997, pp. 573-577. http://dx.doi.org/10.1016/S0176-1617(97)80321-5

[3] G. Nie and S. D. Aust, "Effect of Calcium on the Reversible Thermal Inactivation of Lignin Peroxidase,” Archives of Biochemistry and Biophysics, Vol. 337, No. 2, 1997, pp. 225-231. http://dx.doi.org/10.1006/abbi.1996.9770

[4] G. Nie and S. D. Aust, "Spectral Changes of Lignin Peroxidase during Reversible Inactivation,” Biochemistry, Vol. 36, No. 17, 1997, pp. 5113-5119. http://dx.doi.org/10.1021/bi962583o

[5] B. Alberts, A. Johnson, J. Lewis, M. Raff, K. Roberts and P. Walters, "Molecular Biology of the Cell," 5th Edition, Garland Science, New York, 2007.

[6] J. Sambrook and D. W. Russell, "Molecular Cloning, A Laboratory Manual Vol. 1,” Cold Spring Harbor Laboratory Press, New York, 2001.

[7] S. C. Fry, "Polymer-Bound Phenols as Natural Substrates of Peroxidases,” In: H. Greppin, C. Penel and Th. Gaspar, Eds., Molecular and Physiological Aspects of Plant Peroxidases, University of Geneva, Geneva, 1986, pp. 169182.

[8] L. Sticher, C. Penel and H. Greppin, "Calcium Requirement for the Secretion of Peroxidases by Plant Cell Suspensions,” Journal of Cell Science, Vol. 48, No. 1, 1981, pp. 345-353.

[9] S. Kwak, S. Kim, I. Park and J. Liu, "Enhancement of Peroxidase Activity by Stress-Related Chemicals in Sweet Potato," Phytochemistry, Vol. 43, No. 3, 1996, pp. 565568. http://dx.doi.org/10.1016/0031-9422(96)00315-9

[10] J. H. Dodd and L. W. Roberts, "Experiments in Plant Tissue Culture,” Cambridge University Press, Cambridge, 1985.

[11] O. H. Lowry, N. J. Rosenbrough, A. L. Lewis-Farr and R. Randall, "Protein Measurements with Folin Phenol Reagent,” Journal of Biological Chemistry, Vol. 193, No. 1, 1951, pp. 265-275.

[12] Y. H. Kim and J. Y. Yoo, "Peroxidases Production form Carrot Hairy Root Cell Culture,” Enzyme and Microbial Technology, Vol. 18, No. 7, 1996, pp. 531-535. http://dx.doi.org/10.1016/0141-0229(95)00168-9

[13] M. A. Habib, I. M. I. Ismail, A. J. Mahmood and M. R. Ullah, "Decolourization and Mineralization of Brilliant Golden Yellow (BGY) by Fenton and Photo-Fenton Processes," African Journal of Pure and Applied Chemistry, Vol. 6, No. 14, 2012, pp. 153-158.

[14] P. K. Hepler, "Calcium: A Central Regulator of Plant
Growth and Development,” The Plant Cell, Vol. 17, No. 8, 2005, pp. 2142-2155. http://dx.doi.org/10.1105/tpc.105.032508

[15] G. W. Zhang, Z. Liu, J. Zhou and Y. L. Zhu, "Effect of $\mathrm{Ca}\left(\mathrm{NO}_{3}\right)_{2}$ Stress on Oxidative Damage, Antioxidant Enzyme Activities and Polyamine Contents in Roots of Grafted and Non-Grafted Tomato Plants,” Plant Growth Regulation, Vol. 56, No. 1, 2008, pp. 7-19. http://dx.doi.org/10.1007/s10725-008-9281-8

[16] H. Xu, X. Sun, X. Yang, Q. Shi and X. Wang, "Physiological Responses to Nitrate Stress of Transgenic Tobacco Plants Harbouring the Cucumber Mitogen-Activated Protein Kinase Gene,” Turkish Journal of Botany, Vol. 37, No. 1, 2013, pp. 130-138.

[17] S. A. Abo-Farah, "Comparative Study of Oxidation of Some Azo Dyes by Different Advanced Oxidation Processes: Fenton, Fenton-Like, Photo-Fenton and PhotoFenton-Like,” American Journal of Science, Vol. 6, No. 10, 2010, pp. 128-142.

[18] M. Stanisavljević and L. Nedić, "Removal of Phenol from Industrial Wastewaters by Horseradish (Cochlearia armoracia L.)," Working and Living Environmental Protection, Vol. 2, No. 4, 2004, pp. 345-349.

[19] V. L. Maddhinni, H. B. Vurimindi and A. Yerramilli, "Degradation of Azo Dye with Horseradish Peroxidase (HRP)," Journal of the Indian Institute of Science, Vol. 86, No. 5, 2006, pp. 507-514.

[20] I. Morishima, M. Kurono and Y. Shiro, "Presence of Endogenous Calcium Ion in Horseradish Peroxidase," The Journal of Biological Chemistry, Vol. 261, No. 20, 1986, pp. 9391-9399.

[21] C. Penel, "The Role of Calcium in the Control of Peroxidase Activity,” In: H. Greppin, C. Penel and Th. Gaspar, Eds., Molecular and Physiological Aspects of Plant Peroxidases, University of Geneva, Geneva, 1986, pp. 155-164.

[22] A. Oscar, V. Moreno, R. Vazquez-Duhalt and J. L. Ochoa, "Peroxidase Activity in Calluses and Cell Suspension Cultures of Radish Raphanus sativus var. Cherry Bell," Plant Cell, Tissue and Organ Culture, Vol. 18, No. 3, 1989, pp. 321-327. http://dx.doi.org/10.1007/BF00043401

[23] M. Laberge, Q. Huang, R. Schwietzer-Stenner and J. Fidy, "The Endogenous Calcium Ions of Horseradish Peroxides C Are Required to Maintain the Functional Nonplanarity of the Heme,” Biophysical Journal, Vol. 84, No. 4, 2003, pp. 2542-2552. http://dx.doi.org/10.1016/S0006-3495(03)75059-0

[24] C. Indiani, B. D. Howes, A. Feis and G. Smulevich, "Calcium Depletion of Horseradish Peroxidase Generates a Quantum Mechanical Mixed-Spinheme State,” In: J. Greve, G. J. Puppels and C. Otto, Eds., Spectroscopy of Biological Molecules: New Directions, Springer, Dordrecht, 1999, pp. 145-146. http://dx.doi.org/10.1007/978-94-011-4479-7_62

[25] Y. Shiro, M. Kurono and I. Morishima, "Presence of Endogenous Calcium Ions and Its Functional and Structural Regulation in Horseradish Peroxidase," The Journal of Biological Chemistry, Vol. 261, No. 20, 1986, pp. 93829390. 